\title{
СУЧАСНИЙ СТАН ВИРОБНИЧОЇ ПРАКТИКИ У ПІДГОТОВЦІ ФАХІВЦІВ 3 ВИЩОЮ ФАРМАЦЕВТИЧНОЮ ОСВІТОЮ В УКРАЇНІ
}

\author{
С. В. Огарь, О. Я. Барковська
}

Наџіональний фармачевтичний університет

\section{MODERN STATUS OF MANUFACTURING PRACTICE IN TRAINING OF SPECIALISTS WITH HIGHER PHARMACEUTICAL EDUCATION IN UKRAINE}

\author{
S. V. Ohar, O. Ya. Barkovska \\ National Pharmaceutical University
}

\begin{abstract}
У статті представлений сучасний стан виробничої практики у підготовці фахівців з вищою фармацевтичною освітою в Україні. Наведені результати соціологічного дослідження студентів Національного фармацевтичного університету на тему “Організація практики студентів” та визначені основні чинники, що впливають на якість проходження практики.
\end{abstract}

The article deals with modern status of manufacturing practice in training of specialists with higher pharmaceutical education in Ukraine. The given results of sociological research of students from National University of Pharmacy entitled «Organization of students' practice» and identified main factors influencing on the practice training quality.

Вступ. Поглиблення реформування системи підготовки фахівців для фармацевтичної галузі як складової системи розвитку охорони здоров'я України вимагає нових підходів до організації навчального процесу з метою повноцінного формування професійної компетентності майбутніх провізорів.

Сучасні кваліфікаційні вимоги до випускників пов'язані з соціально-економічними змінами суспільного розвитку і базуються на володінні практичними вміннями і навичками, здібностями оперативно адаптувати теоретичні знання до вимог практичної діяльності.

Підготовка фармацевтичних кадрів в Україні регламентується законодавчими та нормативними актами, що покликані створити умови для найбільш якісної організації освітніх процесів, для приведення якості навчання у відповідність до міжнародних стандартів та вимог інтеграції вітчизняної вищої освіти в міжнародний освітній простір.

Динамічний розвиток фармацевтичної галузі, особливості роботи фармацевтичних організацій, з одного боку, та реформування вищої освіти - 3 іншого, актуалізують проблеми модернізації практичної складової студентів фармацевтичних спеціальностей і в умовах сьогодення набувають актуальності.

Проблемні аспекти виробничої практики з урахуванням специфіки виробництва за різними спеціаль- ностями відображені в працях вітчизняних і російських авторів: С. Батишева, М. Киньколіха, М. Пальчук, Т. Попової, В. Савченко, В. Скакуна, Ю. Сухарнікова [1]. Окремі питання підготовки кадрів для фармацевтичної галузі досліджені вченими Національного фармацевтичного університету В. П. Черних, I. А. Зупанцем, 3. М. Мнушко, А. С. Немченко, В. М. Толочко, Л. Г. Кайдаловою.

Незважаючи на всі дослідження з даного питання, незначна увага приділяється дослідженню практичної складової процесу підготовки фахівців для фармацевтичної галузі.

Основна частина. Метою нашої роботи $€$ вивчення теоретичних основ практики у підготовці фахівців 3 вищою фармацевтичною освітою та представлення результатів соціологічного дослідження “Організація практики студентів".

За даними фармацевтичної енциклопедії, виробнича практика $\epsilon$ однією із форм навчання (організації навчального процесу), невід'ємною складовою частиною процесу підготовки фахівців (обов'язковим компонентом освітньо-професійних програм), основним завданням якої є якість практичної підготовки випускника за освітньо-кваліфікаційним рівнем: бакалавр, спеціаліст, магістр і проводиться на оснащених відповідним чином сучасних підприємствах, організаціях різних галузей господарства. Від якості

(C) С. В. Огарь, О. Я. Барковська 
виконання завдань у період практики залежить професійне становлення майбутнього фахівця [2].

Проведення практики здійснюється згідно з існуючою нормативною базою в Україні $[3,4]$ і має на меті закріплення теоретичних знань, які були отримані в процесі навчання, формування професійного вміння приймати самостійні рішення в певних виробничих умовах, оволодіння сучасними методами, формами організації, знаряддями праці в галузі майбутньої спеціальності, виховання потреби систематично поновлювати свої знання та творчо їх застосовувати в практичній діяльності.

Практика студентів передбачає послідовність ії проведення при одержанні достатнього обсягу теоретичних знань для оволодіння певним рівнем умінь і навичок.

За змістом і метою практика студентів для кожної спеціальності та освітньо-кваліфікаційних рівнів може бути: ознайомлювальна, пропедевтична, навчальна, виробнича, технологічна, переддипломна практика та стажування [5].

Ознайомлювальна практика, пропедевтична - початкова ланка практичної підготовки, яка дає змогу студентам вже на першому курсі навчання мати більш чітке уявлення про свою майбутню професію та більш свідомо підходити до вивчення спеціальних дисциплін. Вона призначена для первинного ознайомлення студентів із різними видами практичної діяльності з обраної спеціальності і покликана сприяти формуванню у них необхідних професійних ціннісних орієнтирів.

Навчальна практика - частина навчального процесу відповідної дисципліни, під час якої студенти набувають реальної обізнаності щодо втілення тих знань, які вони одержали протягом вивчення дисципліни. Завданням навчальної практики є отримання первинних професійних умінь у виробничих умовах $\mathrm{i}$ проводиться у формі залучення студентів до виконання певної роботи за обраною спеціальністю на базах практики.

Виробнича практика проводиться після опанування теоретичної частини відповідної дисципліни. Метою виробничої практики є закріплення знань, відпрацювання вмінь і навичок в умовах майбутньої фахової діяльності. Під час виробничої практики студент виконує обов'язки спеціаліста на робочому місці (при безпосередньому керівництві з боку спеціаліста); усвідомлює організаційну структуру підприємства, де відбувається виробнича практика, сприймає загальну картину всього об’ єкта практики.

Технологічна практика передбачає знайомство студентів-практикантів безпосередньо на підприємствах, установах, організаціях з виробничим процесом і технологічним циклом виробництва, закріплення знань, отриманих при вивченні певного циклу теоретичних дисциплін, та набуття первинного практичного досвіду.

Переддипломна практика передбачає збір та систематизацію матеріалу для дипломного проекту, закріплення теоретичних знань та формування умінь $\mathrm{i}$ навичок відповідно до вимог стандарту освіти та змісту практики, оволодіння професійним досвідом та готовністю до самостійної роботи.

Стажування є завершальним етапом навчання i проводиться 3 метою узагальнення та вдосконалення знань, практичних умінь і навичок на базі конкретного суб'єкта господарювання, оволодіння професійним досвідом та готовності майбутнього фахівця до самостійної трудової діяльності. Мета стажування полягає у підготовці майбутніх спеціалістів до самостійного виконання професійних функцій на певній посаді.

Перелік усіх видів практик для кожної спеціальності, їх форми, тривалість і терміни проведення визначаються в навчальних планах.

Основним навчально-методичним документом практичної підготовки є наскрізна програма практики студентів, яка розробляється кафедрою згідно 3 навчальним планом, затверджується керівником вищого навчального закладу, регламентує мету, зміст і послідовність проведення практики, підведення підсумків, містить рекомендації щодо видів, форм і методів контролю якості підготовки на базі практики (рівень знань, уміння і навички). На основі наскрізної програми щорічно розробляються робочі програми відповідних видів практики.

Практика проводиться в умовах професійної діяльності під організаційно-методичним керівництвом викладача університету та спеціаліста з даного фаху.

За даними фармацевтичної енциклопедії, базою практики може бути установа, підприємство, організація різних форми власності та підпорядкованості, що придатна для проведення практики студентів і забезпечує виконання програми практики для відповідного освітньо-кваліфікаційного рівня. Практика проводиться на підставі договорів, тривалість дії яких погоджується договірними сторонами. Вона може визначатись на період конкретного виду практики або до п’яти років. Залежно від обраної спеціальності (Фармація, Клінічна фармація, Технологія парфумерно-косметичних засобів, Технологія фармацевтичних препаратів), базою практики можуть бути: аптеки, аптечні склади, контрольно-аналітичні лабораторії, зональні дослідні станції, хіміко-фармацевтичні підприємства, 
косметичні салони та кабінети, парфумерно-косметичні підприємства, лікувальні заклади, клініко-діагностичні центри, клінічні лабораторії [2].

У Національному фармацевтичному університеті проводилося соціологічне дослідження на тему “Організація практики студентів”, мета якого - дослідження рівня задоволеності студентів процесом проходження практики. В опитуванні взяли участь студенти 4-5 курсів.

На запитання про загальне враження студентів про практику відповіді розподілилися таким чином: сприятливе - 46,2 \%, швидше сприятливе, ніж несприятливе $-38,5 \%$, швидше несприятливе, ніж сприятли- ве $-7,7 \%$, важко відповісти - $5 \%$, несприятливе $2,6 \%$, на запитання "Наскільки Ви професійно адаптувалися до професійної діяльності у процесі практики?” - студенти відповіли: здебільшого адаптувався $-59 \%$, повністю адаптувався - 17,9\%, важко відповісти $-12,8 \%$, не адаптувався - $10,3 \%$, на запитання "Чи виникали у Вас під час практики стани психологічного дискомфорту?” були отримані такі відповіді: ні, не виникали $-61,5 \%$, так, зрідка $-25,6 \%$, так, періодично - 10,3\%, так, часто - 2,6\%.

Студентам було запропоновано проаналізувати практику з точки зору їі корисності. Результати зазначені у таблиці 1.

Таблиця 1. Результати практики з точки зору іiі корисності

\begin{tabular}{|c|l|c|c|c|}
\hline $\begin{array}{c}\text { № } \\
\text { за/п }\end{array}$ & \multicolumn{1}{|c|}{ Питання } & $\begin{array}{c}\text { Повною } \\
\text { мірою, } \%\end{array}$ & Частково, \% & Не зумів, \% \\
\hline 1 & Зрозумів мету навчання & 55,30 & 42,10 & 2,60 \\
\hline 2 & Навчився планувати свою діяльність & 31,60 & 60,50 & 7,90 \\
\hline 3 & Дізнався про нові технології & 23,70 & 39,50 & 36,80 \\
\hline 4 & Знайшов свій стиль роботи & 7,70 & 59,00 & 33,30 \\
\hline 5 & $\begin{array}{l}\text { Переконався в правильності вибору своєї майбутньої } \\
\text { професії }\end{array}$ & 31,60 & 50,00 & 18,40 \\
\hline 6 & Поглибив свої знання з дисциплін спеціалізації & 44,70 & 47,40 & 7,90 \\
\hline
\end{tabular}

На запитання “Чи створені під час практики умови для прояву активності та творчої самореалізації студентів?" відповіді розподілилися таким чином: частково створені - 56,4 \%, такі умови не створено $-33,3 \%$, так, повною мірою - 10,3\%, на запитання "Чи був процес проходження практики для Вас складним?” було виявлено, що процес походження практики був помірної складності для 25,6 \% опитаних, та взагалі не виникало труднощів у 73,4 \% опитаних.

Крім того, студентам було запропоновано дати оцінку результативності минулої практики в балах за п'ятибальною системою оцінювання. Були отримані такі результати: 2 бали - 15,4 \%, 3 бали - 25,6 \%, 4 бали $43,6 \%, 5$ балів - 15,4 \%, на запитання "Чи достатня

\section{Лiтература}

1. Усеінова Л. Ю. Формування професійно-практичної компетентності майбутніх інженерів-педагогів в умовах виробничої практики : автореферат дисертації на здобуття наукового ступеня кандидата педагогічних наук / Л. Ю. Усеінова. -К., 2010.

2. Фармацевтична енциклопедія / голова ред. ради та автор передмови В. П. Черних. - [2-ге вид., переробл. і доповн.]. -К. : МОРІОН, 2010. -1632 с.: іл. 16 с.

3. Про затвердження Положення про проведення практики студентів вищих навчальних закладів України : наказ тривалість практики для засвоєння програми практики?” відповіді були такі: так, цілком достатня - 61,5 \%, тривалість практики повинна бути більшою - 25,6 $\%$, тривалість практики повинна бути меншою - 7,8 \%, важко відповісти - 5,1\%.

На запитання "Чи задовольняє Вас існуюча форма організації та проведення практики?” студенти відповіли таким чином: так, задовольняє $-79,5 \%$, не задовольняє $-18 \%$, важко відповісти $-2,5 \%$.

В наступній публікації буде визначена роль виробничої практики, проаналізовані проблеми ії організації.

Висновок. Вивчені теоретичні основи практики як невід'ємної складової частини процесу підготовки фахівців та представлені результати соціологічного дослідження “Організація практики студентів”.

Міністерства освіти України № 93 від 8 квітня 1993 року.

4. Про затвердження Інструкції про виробничу практику студентів медичного, лікувального, педіатричного, медикопрофілактичного, стоматологічного і фармацевтичного факультетів медичних і фармацевтичного вищих навчальних закладів III-IV рівнів акредитації : наказ Міністерства охорони здоров’я України № 179 від 3 жовтня 1995 року.

5. Положення про практику в Національному фармацевтичному університеті / [В. П. Черних, В. М. Толочко, С. В. Огарь та ін.]. - Х. : Вид-во НФаУ, 2004. - 16 с. 